\title{
Village Potential Mapping to Initiate the Establishment of BUMDes in Indonesia
}

\author{
Nova Maulud Widodo ${ }^{1}$, RB. Iwan Noor Suhasto ${ }^{2}$, Sasmito Widi Nugroho ${ }^{3}$ \\ State Polytechnic od Madiun, Jalan Serayu No. 84 Madiun, East Java, Indonesia ${ }^{1}$ \\ \{novamaulud@pnm.ac.id ${ }^{1}$ \}
}

\begin{abstract}
The establishment of Village-Owned Enterprises (BUMDes) is the mandate of the law. BUMDes is also one of the leading work programs in the government's priority performance. The limited meeting of the President of the Republic of Indonesia on September 24, 2020, invited the village government to carry out development synergy. Although 5000 BUMDes are targeted by the Ministry of Villages, Disadvantaged Areas and Transmigration it has been surpassed by the establishment of nearly 35,000 BUMDes across Indonesia. However, there are some villages that still seem hesitant and less motivated to establish BUMDes. Kawedanan District consists of seventeen villages and three sub-districts. There are a large number of villages in Kawedanan District but not all villages have established BUMDes. The purpose of this study was to determine the potential of the village in the initiation of establishing BUMDes in Kawedanan District. This research activity was carried out qualitatively, through initial surveys, interviews, field studies on village potential mapping. The result of this activity is a document on mapping village potential and selecting a BUMDes company plan.
\end{abstract}

Keywords: Government Accounting, BUMDes, Village Government

\section{Introduction}

The village as smallest political unit government, village has a strategic position in government structure. Villages have strategic position; this is a pillar of national development in Indonoseia. The village has a lot of potential, both in terms of population but also the availability of abundant resources. If these two potentials can be maximally managed, it will provide welfare for the population. So far, the village is considered an area that still has limitations, both in terms of human resources and welfare.

Today it's realized that development at the village level still has weaknesses. The weakness of development in the village government, among others, is due to the problem of human resources that are less qualified but also because of financial problems. These various efforts have been made by the government by pouring out various funds for village development programs, one of which is the government's efforts through the establishment of Village-Owned Enterprises (BUMDes) at the village government level.

Kawedanan District is one of the sub-districts in Magetan Regency which has seventeen villages and three sub-districts. The BUMDes establishment stage consists of at least 8 stages 
[1], namely (1) disseminating the plan to form BUMDes, (2) forming a preparation team for the establishment of BUMDes, (3) mapping village potential and selecting priority types of business, (4) drafting Raperdes and statutes of BUMDes, (5) preparation of Musdes implementation, (6) implementation of village meetings, (7) issuance of Perdes as the basis for establishing Bumdes, and (8) recruitment and inauguration of Bumdes managers.

Based on the background above, the researchers formulated the problem formulation, namely how to map the village potential in the context of initiating the formation of BUMDes in Kawedanan District. The author limits the problem to avoid widening the problem in the study. The following are the problem limitations in this study:

a) The research was conducted in Kawedanan District, Magetan Regency in 2020

b) The research object is the Village Government

c) Scope of research on BUMDes

Based on the furmulation of the problem above, author's aim in conducting this research is to map the village potential in the context of initiating the formation of BUMDes in Kawedanan District.

\section{Theory}

Regional autonomy is part of the political system which is expected to provide opportunities for citizens to be more able to contribute their creative power. Thus, regional autonomy is a necessity in the era of globalization and reform. Without regional autonomy, people will have difficulty placing themselves equal to other human beings in various countries when free trade comes into effect.

Law No.32 of 2004 on regional governance also mentions village governance, which is then specifically regulated in Government Regulation (PP) No.72 of 2005 concerning Villages as one of the implementing rules of Law No.32 of 2004. So, actually now there is a regulation that specifically regulates villages, but the regulation is at the PP level and not a law [2]. The definition of a village according to Government Regulation No. 72 of 2005 is a legal community unit that has territorial boundaries that are authorized to regulate and manage the interests loccal community, based on loccal origins and customs that are recognized and respected in the Government of the Unitary State of the Republic of Indonesia [3].

In Law Number 32 of 2004 and Government Regulation Number 72 of 2005, it is mandated that in increasing community and village income, the village government can establish BUMDes according the needs and very potential on the village. In terms of participatory and emancipatory principles, planning and formation, BUMDes is built on initiative, and is based on cooperative, with two underlying principles, namely member base and self-help.

\section{Method}

This type of research used type is qualitative research with the descriptive approach. A theoretical basis in understanding the qualitative method approach defines qualitative methods as research procedures that descriptive produce data the form of spoken or written words for people and observable behavior [4]. Descriptive is a report that contains excerpts of data to provide an overview of the report presentation. The data comes from observations and documentation obtained from the sample. This research use purposive sampling. The location 
of this research will be carried out in Kawedanan District, Magetan, Indonesia. The object studied used a purposive sampling method, namely the potential of BUMDes in the village of Kawedanan District

Conducting a study is inseparable from the existence of data which will later become information material to provide an overview of the specifications regarding the object of research. The data used in the study include:

a) Primary Data

Primary data define the data obtained by researcher directly from the object under study. This is were obtained through interviews with the village government regarding the problems being studied. The primary data obtained includes Village Potential and BUMDes [5].

b) Secondary Data

Secondary data define data obtained from published documents that have finished form. The secondary data in this study consists of financial data from foundations, books, articles, journals, and so on [5].

This study uses data related to the process of preparing financial statements. The author collected data using several methods, namely:

a) Observation

Observation according to Herdiansyah (2013) is a process of seeing, observing, and observing and recording systematic behavior for a specific purpose. This observation method is used to see first-hand the activities in Kawedanan District. An interview is a conversation between two people where one of them aims to explore and get information for a specific purpose [6]. This interview method was used to obtain information related to the potential of the BUMDes being studied in the Kawedanan District.

b) Documentation

Documents are records of events that have passed. Documents can be in the form of writings (diaries, life histories, stories, biographies, regulations, policies), drawings (photographs, living pictures, sketches, etc.), or monumental works of a person (works of art: drawings, sculptures, films, etc.) [7].

This method is used to obtain data related to this research. Data analysis technique is the process of collecting data systematically to facilitate researchers in obtaining conclusions. The qualitative data analysis is inductive, namely the analysis is based on the data obtained. Data analysis used the Interactive Model according to Miles and Hubberman [8]. Analysis of this interactive model through 3 stages, namely data reduction, data presentation, and drawing conclusions/verification.

a) Data Reduction

Data reduction defined as the selecting process, abstracting, focusing on simplifying, and transforming raw data that emerge from written records in the field. Data reduction takes place continuously during a qualitative research-oriented project. Anticipation of data reduction is evident when the research decides the research problems, conceptual framework, research area, and which data collection approach. During data collection, the next stage of reduction takes placce. This data reduction / transformation continues after the field research, until the final report is complete. Data reduction is analysis parts. Data reduction is a form analysis that classifies, sharpens, directs, removes unnecessary, and data organizes in such a way that final conclusions can be drawn and verified. With reduction data, the researcher does not need to interpret it as quantification. Qualitative 
data can be simplified and transformed in a variety of ways, namely: through rigorous selection, through summaries or brief descriptions, categorizing them into a broader pattern, and so on. Sometimes it is possible to transform data into numbers or ranks, but this is not always wise.

b) Presentation of Data

As an organized set of information that gives the possibility of drawing conclusions and taking action. Better representations are a major means of valid qualitative analysis, which includes: various types of matrices, networks, graphs and charts. Everything is designed to combine organized information in a coherent and easily accessible form. This analyzer can see what is going on, and determine whether to draw the correct conclusions or continue carry out the analysis according to the suggestions narrated by the presentation as something that might be useful.

c) Withdrawal of conclusions

Drawing conclusions according to Miles \& Huberman is only part of one activity from an intact configuration. Conclusions were also verified throughout the study. The verification may be as short as a rethink that crosses the mind of the analyzer (researcher) as he writes, a review of field notes, or it may become exhaustive and exhausting with peer review and brainstorming to develop an intersubjective agreement or also extensive attempts to place a copy of a finding in another data set. In short, the meanings that emerge from other data must be tested for their validity, robustness and suitability, that is, their validity. The final conclusion does not only occur during the data collection process, but needs to be verified so that it can be truly accounted for. Schematically, the data analysis process uses the interactive data analysis model Miles and Huberman can be seen in the following chart:

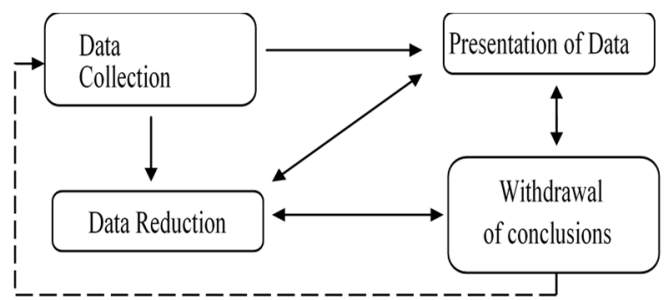

Fig. 1. Analisis Model Data Interaktif Miles and Huberman

\section{Result and Discussion}

Based on the research data we obtained, Kawedanan District consists of 3 Kelurahan, namely 1 to 3 and 17 Villages, as in the table as follows:

Table 1. List of Villages / Kelurahan in Kawedanan District

\begin{tabular}{clcc}
\hline No. & Village & An area (KM) & Pos Code \\
\hline 1 & Kawedanan & 2.12 & 63882 \\
2 & Rejosari & 0.37 & 63882 \\
3 & Sampung & 1.24 & 63882 \\
4 & Giripurno & 4.02 & 63882 \\
5 & Ngentep & 2.01 & 63882 \\
6 & Balerejo & 1.73 & 63882 \\
7 & Garon & 2.63 & 63882 \\
8 & Tladan & 3.60 & 63882 \\
\hline
\end{tabular}




\begin{tabular}{clcc}
\hline No. & Village & An area $(\mathbf{K M})$ & Pos Code \\
\hline 9 & Pojok & 1.46 & 63882 \\
10 & Tulung & 2.63 & 63882 \\
11 & Ngunut & 0.90 & 63882 \\
12 & Mangunrejo & 2.31 & 63882 \\
13 & Selorejo & 3.08 & 63882 \\
14 & Jambangan & 1.21 & 63882 \\
15 & Bogem & 1.00 & 63882 \\
16 & Mojorejo & 1.67 & 63882 \\
17 & Genengan & 2.18 & 63882 \\
18 & Karangrejo & 2.42 & 63882 \\
19 & Ngadirejo & 1.62 & 63882 \\
20 & Sugihrejo & 2.31 & 63882 \\
\hline \multicolumn{3}{c}{ Source: Data processed by the author, 2020. }
\end{tabular}

Based on the profile of Kawedanan District, Magetan Regency is to the east of Magetan City. The Kawedanan Subdistrict Office is located in Kawedanan Village with the coordinates of 7,69225 LS and 111,41819 East Longitude with a height of 162 meters above sea level. The area of Kawedanan District is around $39.44 \mathrm{~km} 2$ or $5.7 \%$ of the total area of Magetan Regency with the widest village being Giripurno Village with an area of $402.34 \mathrm{Ha}$. 53\% of the Kawedanan Subdistrict is agricultural rice fields. North boundary of Kawedanan District: Sukomoro District and East Bendo District: South Nguntoronadi District: Lembeyan District and West Parang District: Ngariboyo District and Parang District.

Based on the research of Harjanti Widiastuti, Elik Kresnawati and Evy Rahman Utami (2019), Village Potential Mapping is measured using 7 indicators, in this case the landscape, namely Nature, Social, Economy, Technology, Human Resources, Markets, and the Environment. In this study, the researcher will present the landscape according to the indicators put forward by Harjanti et al in each of the research sample villages in Kawedanan District, Magetan Regency.

Table 2. Mapping the Potential of Giripurno Village

\begin{tabular}{|c|c|c|}
\hline No & Span & $\begin{array}{ll}\text { Giripurno Village } \\
\end{array}$ \\
\hline 1 & Natural & $\begin{array}{l}\text { a. Extensive agricultural land } \\
\text { b. There is a Community Forest } \\
\text { c. There is Bancak Hill } \\
\text { d. Limited irrigation }\end{array}$ \\
\hline 2 & Social & $\begin{array}{l}\text { a. Institutional relations in the village are running well } \\
\text { b. Community leaders are actively involved in Village Deliberations }\end{array}$ \\
\hline 3 & Economy & $\begin{array}{l}\text { a. Low Purchasing Power } \\
\text { b. There is a risk of harvest failure } \\
\text { c. Middle and lower society economy }\end{array}$ \\
\hline 4 & Technology & Less technology \\
\hline 5 & Market & $\begin{array}{l}\text { a. There is only krempyeng market in the morning } \\
\text { b. Less community competition }\end{array}$ \\
\hline 6 & Human Resources & $\begin{array}{l}\text { a. The spirit of mutual cooperation is high } \\
\text { b. Guyup's life is harmonious }\end{array}$ \\
\hline 7 & Environment & $\begin{array}{l}\text { a. There is Maduretno's Tomb on the Top of the Hill } \\
\text { b. There is a sacred event in Muharram (Suro) }\end{array}$ \\
\hline
\end{tabular}


The results of the landscape mapping show that Giripurno Village has the potential to be packaged into tourism, in this case it is more towards religious tourism. Giripurno village has great agricultural and forest product potential, especially in Kawedanan. This can be used as a potential for hill tourism combined with historical assets and forest products that can be increased in economic value.

The results of the economic landscape indicate that Giripurno Village has a poor economy, this is evidenced by the fact that several hamlet areas have only been established by electricity and clean water channels. Market availability is also far from good, we still find people there selling at the T-junction in the morning. We can maximize all these shortcomings to become a tourist attraction combined with the available human resources of Giripurno Village. We will present the results of other village landscapes in the research appendix.

Based on the results of the BUMDes initiation, we know that the location of Kawedanan District is traversed by three rivers. This natural condition causes rivers to pass almost all villages in Kawedanan District, except for Giripurno Village. Although it is not traversed by a river, Giripurno Village has irrigation. This makes all villages in Kawedanan District have livelihoods as farmers.

The results of the research on the social landscape were not so different between each village in the Kawedanan District. There is a slight difference in the economic landscape, villages that are close to the main road and close to the center of the crowd have a better economy than those located far from the sub-district center. This includes the market landscape, which is an indication of the community's competitiveness, including market availability.

Aspects of human resources and the environment are no less important in initiating the mapping of BUMDes in Kawedanan District. The availability of five spans if it is not supported by good resources and a supportive environment, of course it will be difficult to produce a superior BUMDes. Therefore, the seven aspects must work together in the development of Village-Owned Enterprises in Kawedanan District, Magetan Regency.

Of the 17 Villages in Kawedanan District, we can conclude that BUMDes which are engaged in trade are the most likely to be realized, followed by shop houses, savings and loan businesses and the tourism sector. In terms of establishing the BUMDes, it would be better if all parties synergize with each other, the villages also communicate in synergy, as stated by President Joko Widodo in a limited meeting about accelerating village economic development.

\section{Conclusion}

Based on the results and discussion, the authors draw the following conclusions:

a) The initiation of BUMDes mapping in Kawedanan District was measured through 7 spans,

b) The seven mapping landscapes are all important in the BUMDes initiation process,

c) Seventeen Villages in Kawedanan District, Magetan Regency can be mapped the potential of BUMDes.

Based on the above conclusions, the author's suggestion is that all villages in Kawedanan District, Magetan Regency can immediately compile BUMDes by considering the seven spans that each village has. 


\section{References}

[1] R. Suryanto, Peta Jalan Bumdes Sukses (Pertama). Yogyakarta: PT. Syncore Indonesia, 2018.

[2] "Undang - Undang Nomor 32 Tahun 2004 tentang Pemerintah Daerah.” Direktoral Jenderal Otonomi Daerah, Jakarta.

[3] "Peraturan Pemerintah Nomor 72 Tahun 2005. tentang Desa." Direktorat Jendral Otonomi Daerah, Jakarta.

[4] L. J. Moleong, Metode Penelitian Kualitatif. Bandung: Remaja Rosdakarya, 2002.

[5] J. Soewadji, Pengantar Metodologi Penelitian. Jakarta: Mitra Wacana Media, 2012.

[6] H. Herdiansyah, Wawancara Observasi dan Fokus Groups Sebagai Instrumen Penggalian Data Kualitatif. Jakarta: Rajawali Press, 2013.

[7] Sugiyono, Metode Penelitian Kuantitatif Kualitatif dan R\&D. Bandung: Alfabeta, 2017.

[8] H. U. Akbar and P. Setiady, Metodologi Penelitian Sosial. Jakarta: Bumi Aksara, 2009. 